\title{
NWLC 2012 - Report from the Conference in Elsinore, Denmark, April 2012
}

\author{
I Klaus T. Nielsen \\ Associated professor, Centre for Working Environment and Working Life, Roskilde University, \\ Denmark
}

rom 25th to 27th of April 2012, the 6th Nordic Working Life Conference took place at LO-skolen in Elsinore, Denmark. LO-skolen, the School of the Danish Confederation of Trade Unions, a beautiful place with a long tradition of educating Danish trade union representatives, shop stewards, and safety reps, located with an excellent sight over the narrow waters between Denmark and Sweden, filled with many inspiring pieces of modern Danish art, and for this occasion around 130 working life researchers, was the perfect spot for this conference. The conference series seems to have a mysterious past as some of the old-timers at the conference came up with competing suggestions for the first couple of conferences, but there was an agreement on that the last conference was in Stavanger thirteen far too long years ago.

Perhaps one reason for the long wait has been a general feeling that the Europeanization and globalization of both work and research (publication expectations in particular) might make the Nordic forum less relevant than other forums. However, there seemed to be a widespread recognition at this conference that such conclusions had proven too hasty and inadequate. Nordic researchers still have a lot to exchange and share if they want to make an impact on the international agenda as well.

I was asked to summarize and reflect on what I heard at the conference. Based on that I made a presentation at the closing session of the conference - and I write this short report. But I have no intention to adequately summarize the papers and the conference. I haven't read more than a small fraction of the papers and only heard some $20 \%$ of the workshop presentations at the conference. What I present here is fairly kaleidoscopical there are patterns, but I might be the only one that sees this particular version of them; I make no excuse for that.

The conference was nicely framed by Lisbeth Pedersen, head of the Research Unit on Employment and Labour Market Issues, at one of the co-organizers of the conference, The Danish National Centre for Social Research. In the Danish case, she pointed at the tension between the solutions suggested by the National Welfare Commission in relation to the impact of the rising of life expectancy and globalization and the recommendations suggested by the Danish Family and Working Life Commission. The former commission was heavily committed to increasing the labor supply, whereas the latter commission primarily wanted the labor market to become more accommodating to the needs of parents with young children. Oh yes, we want to maintain our welfare state provisions, but to what extent is that possible?

The first question that did attract attention is the Nordicness of our field and research: In what respect are working life different in the Nordic countries compared with other 
countries, how do we grasp the differences, and to what extent are the features under pressure (as suggested by the subtitle of the conference: Nordic Working Life and Research under pressure) and with what consequences?

That the Nordic countries are special was acknowledge by many speakers. Torsten Björkman, the Swedish keynote speaker, suggested that there is an abundance of European work-related statistics that put the Nordic countries (and often the Netherlands, too) at one end of the scale. A paper by Armi Mustosmäki and colleagues showed this in relation to job quality. And all the other keynote speakers had points in their presentations to the same effect: We are special!

What then is the foundation of this distinctiveness? This question had less prominence, but I would still like to point out a couple of presentations that due to their historical angle touched upon this question. First there was Hansen, Carlsson, and Skorstad, who compared the paper mill of the fifties, which was the empirical foundation of Sverre Lysgaard's (in the Nordic countries) famous study of arbeiderkollektivet, the workers collective, with the same paper mill in the new millennium. They found that the workers collective was still there. Until the mill was shot down almost at the same time as the conference, one might add. But the striking point being that this classical Nordic study apparently made no references to any particularly Nordic model of high trust, low-power distance, or any similar features. Then there was Bernd Schiller's presentation that took us back to the foundation of the labor movement, and in that context to one of the reasons why the relations between employers and workers and their trade unions might be of a less conflictual character in the Nordic countries than elsewhere. The workers of the early industrialization were less subdued since they came from a peasantry not used to such a strong aristocracy as was found in the rest of Europe. There are of course many other reasons why the Nordic countries are special, and there is probably no way to disentangle all these reasons. But I still believe that the attempt to do so might uncover valuable insights into the process of maintaining and reforming the institutional orders on which our societies are based. Apart from the presentations I have mentioned here, a perhaps much stronger thread was woven by the many presentations that touched upon the "gender"- "female employment rates""welfare state"-"working in the public sector" nexus. I shall elaborate this no further, but just make the observation that this complex of issues took up a substantial part of the discussions at the conference.

Looking for the Nordic peculiarities, their prehistory, patterns, and prospects is of course obvious if a Nordic conference is to justify itself to the participants and their funding sources. But there is a need to be cautious: the distance between a sober interest in how and why the Nordic countries are special and a self-righteous and self-promoting position is short.

There is a scale of interests that preoccupy working life scholars and researchers, and that holds for this conference as well. At one end, we have the institutional orders that tend to lump the Nordic countries together under one heading. Moving toward the other end of the scale, we pass industrial relations, studies of how particular changes in society and organizational ideas and practices seem to impact on work, more localized effects of industrial and social relations, and last we end at work as such.

I have already visited the institutional orders and that end of the scale. The study of various trends in working life had at this conference globalization, standardization technologies, lean, and New Public Management (NPM) as focal points. The critical 
backbone of Nordic working life research certainly showed itself in a series of presentations that left very little hope of maintaining or improving the quality of working life if changes could be seen as versions of standardization, lean, or NPM. But at the end of the day, these positions were challenged from other more - for want of a better name - pragmatic positions. In particular, this manifested itself when Peter Hasle, the Danish keynote speaker, spoke up on behalf of lean and argued that a proper review of "the lean and the quality of working life research" shows that there is no regular pattern of working environment deterioration linked to the implementation of lean - indeed lean in many instances improves work as it often takes off from mappings of how work is actually performed. Similar discussions did take place, if less prominently, related to both standardization - that could be seen as a countermeasure to the challenges of boundaryless work - and NPM - which in some aspects was associated with a professionalization of, e.g., care work. However, the majority of papers support the critical rather than the pragmatic position.

In my opinion, I found that a major challenge to our research field, working life research, is the lack of attention to work itself, when listening to the presentations and overlooking the list of papers presented. Indeed, there were other aspects I missed too. I found very few papers struggling with theory as such; the classical battles between Marxists and post-modernist in various guises seem to be a thing of the past, with no new fault lines emerging. Is that a sign of crises in our research field? And I found no true successors to the action research tradition that has been a constituent part of the Nordic working life research since Thorsrud and Emery's social-technical experiments in the 1960s. But most of all I missed papers on work and working: What do people do when they are working and what does work do to people? In my perception, working has at best been substituted with social relations related to work, at worst work has been lost. Without working - work as such - there is no working life, and hence no working life research. I implore you to attend more to work.

At the conference, I showed some pictures of the fountain outside the conference building, one of the major works of modern art that you find at the LO-skolen. The fountain has a series of balls or globes scattered around. Some of the globes sort of unfold into flowerlike pieces, and almost hidden among the petals of the flowers sometimes you see a face. Similarly, I would like to see how working life is infolded in the trends of globalization and the like and the institutional orders, Nordic or otherwise.

Hope to see you at the next Nordic Working Life Conference in Göteborg.

Klaus T. Nielsen 